\title{
Voice Problems and Self-Care Practice for Vocal Health: Current Status of Korean Speech-Language Pathologists
}

\author{
Ji Sung Kima, , Seong Hee Choi ${ }^{\mathrm{c}}$ \\ ${ }^{a}$ Graduate School of Daegu Catholic University, Gyeongsan, Korea \\ ${ }^{b}$ Department of Otorhinolaryngology, Chungbuk National University Hospital, Cheongju, Korea \\ 'Department of Audiology and Speech-Language Pathology, Daegu Catholic University, Gyeongsan, Korea
}

\author{
Correspondence: Seong Hee Choi, PhD \\ Department of Audiology and Speech-Language \\ Pathology, Institute of Biomimetic Sensory Control \\ \& Catholic Hearing Voice Speech Center, Daegu \\ Catholic University, 13-13 Hayang-ro, Hayang-eup, \\ Gyeongsan 38430, Korea \\ Tel: +82-53-850-2542 \\ Fax: +82-53-850-2540 \\ E-mail: shgrace@cu.ac.kr
}

Received: April 10, 2018

Revised: May 26, 2018

Accepted: June 6, 2018

This work is supported by 2017 Capacity development project from The Korean Association of Speech Language Pathologists.
Objectives: Speech-language pathologists (SLPS) have significant demands on their vocal use and their voice problems have a negative impact on their clinical performance. The purpose of this study was to investigate voice problems and self-care among Korean SLPS. Methods: A total of 187 SLPs completed on online or offline survey and then the data was analyzed. The questionnaire addressed experiences with voice-related problems, knowledge and practice of vocal hygiene, vocal overuse and misuse, and the Voice Handicap Index-10 (VHI-10). Results: About 33\% of SLPs had subjective chronic voice problems, about $50 \%$ had voice symptoms of vocal fatigue, hoarseness, and hypertension when speaking. Although the majority of SLPs had knowledge regarding vocal hygiene, lower self-evaluation experiences related to voice use and vocal hygiene practice were reported. With respect to the most common reason for voice problems, SLPs answered 'voice overuse and misuse' (60.2\%) and 'voice use habits' (45.4\%). SLPs also reported 'attention and effort' $(55.1 \%)$ as the main reason for difficulty with voice hygiene practice. SLPs with subjective voice problems showed significant higher voice symptom $(p=.00)$, overuse and misuse $(p=.001), \mathrm{VHI}-10(p=.00)$, and lower voice hygiene practice $(p=.026)$ than SLPs without subjective voice problems. Voice overuse and misuse and VHI-10 were correlated with voice symptoms $(p=.00)$. Conclusion: The voice problems of SLPs may originate from physical fatigue of the phonatory mechanism. SLPs showed a lack of vocal hygiene and vocal health self-care. A vocal hygiene program tailored to individual SLP's specific conditions, along with active self-care practice should be established to reduce vocal fatigue and help SLPS achieve vocal health.

Keywords: Vocal Hygiene, Voice-related experiences, Self-reported voice symptom 언어재활사(speech language pathologist)는 의뢰된 의사소통장 애 환자의 평가를 위한 언어적 자극의 제시나 자극에 따른 반응의 촉진뿐만 아니라 치료과정에서 수립된 치료목표의 달성을 위한 언 어적 모델링이나 자발적인 언어표현을 위한 언어적, 환경적 맥락의 구조화 그리고 평가나 치료 이후 문제의 설명이나 환자나 환자보호 자와의 상담 등의 직무수행을 위해 지속적인 음성사용이 요구된다 는 점에서 음성사용 정도에 따른 직업분류 가운데 음성의 문제가
일을 적절히 유지하는 데 방해가 되는 직업적 음성사용자(professionalvoice user)에 속한다고 볼 수 있다(Koufman \& Isaacson, 1991).

주당 25 회기 이상 치료하는 언어재활사 가운데 $23.4 \%$ 는 스스로 만성적 음성문제가 있다고 생각하는데, 전일제 직업을 가진 여성 직업인 중 음성사용이 많은 직업인이 $8.7 \%$, 일반 직업인 $6.8 \%$ 로 보 고된 것을 고려하면 2 배 이상 높은 수치이다. 음성검사의 필요성에 대해 음성사용이 많은 직업인의 $13.1 \%$, 일반 직업인의 $2.3 \%$, 언어재 
활사의 $43 \%$ 가 필요하다고 느끼는 것으로 나타났으며, 음성문제로 인한 이비인후과 진료경험은 음성사용이 많은 직업인이 $10.9 \%$, 일 반 직업인이 $2.3 \%$ 인 반면, 언어재활사는 $20.9 \%$ 로 더 높았고, 음성 문제로 인한 휴식이나 업무 중단한 경험 역시 음성사용이 많은 직 업인 $4.4 \%$, 일반 직업인 $2.3 \%$ 인 것에 비해 언어재활사는 $12.8 \%$ 로 더 높았다. 또한, 현재 느끼고 있는 음성의 불편함에 대한 주관적 증상이 1 개 이상인 언어재활사는 $60.5 \%$, 음성사용이 많은 직업인 은 $39.1 \%$. 일반 직업인 $54.6 \%$ 였으며, 언어재활사의 주된 증상은 음 성피로(37.2\%), 말할 때 목소리 갈라짐(24.4\%), 노래의 고음발성곤 란(24.4\%)이었으며, 음성사용이 많은 직업인은 노래의 고음발성곤 란(28.3\%)과 저음발성곤란(19.6\%), 말할 때 목소리 갈라짐(19.6\%), 일반 직업인은 노래의 고음발성곤란(29.6\%), 정상 보다 낮은 목소리 (20.5\%)였다. VHI-30에서는 음성사용이 많은 직업인 및 일반 직업 인과 음성증상 유병률에 차이가 없고 기능, 신체, 정서, 전체 점수가 3.9, 8.6, 4.3, 16.8로 그 심한정도(Jacobson et al., 1997)가 정상 범위 에 속하였으나, 신체영역과 VHI-30 전체의 점수가 음성사용이 많 은 직업인과 일반인보다 각각 유의하게 높아 음성증상에 대한 민감 성이 높은 것으로 나타났다(Song \& Pyo, 2010). 또한, 언어치료를 연속으로 2 회 실시하기 전과 후의 음성을 비교한 결과, 기본주파수 (F0), 발화 기본주파수(SFF), 주파수 변동률(jitter), 진폭 변동률 (shimmer), 잡음관련 변수(NHR, VTI, SPI) 등과 같은 음성의 음향 학적 차이는 없었으며, 시각적 아날로그 척도(visual analogue scale, $\mathrm{VAS}$ )로 평가한 음성의 피로도, 목마름, 불편감등의 주관적 음성문 제 정도만 증가하는 것으로 나타났다(Lee, 2017). 주당 30회기 이상 치료하는 언어재활사는 영유아 교사, 학생 및 사무직 직장인과 비 교 시 주파수 변동률(jitter)과 진폭 변동률(shimmer), 소음대 잡음 비(NHR)와같은 음향학적 변수뿐만 아니라음성피로도와음성장 애지수에서도 유의한 차이가 없었다(Kim, 2017).

직업적 음성사용자 가운데 교사나 성직자의 경우 음성문제 발생 의 가장 주요한 원인은 말을 많이 하는 것 또는 말을 많이 할 수 밖 에 없는 것이었고, 유치원교사는 육체적 활동과 자신의 음성이 아 닌 인위적인 음성을 사용해야 하는 것이 주요한 요인이었다. 여성 텔레마케터 역시 높은 음도의 인위적인 음성사용에 영향을 받았 다. 학원강사의 경우는 식습관을 포함한 불규칙한 생활습관이 음 성에 영향을 많이 미쳤다(Cho, 2016; Pyo, 2011; Seo, 2016). 또한, 초 등 여교사는 음성사용습관, 생활환경, 생활습관과 관련된 오남용 중 음성사용습관에 속하는 큰소리로 말하기, 시끄러운 환경에서 말하기, 과도한 말하기나 이야기하기 등이 여교사의 음성장애를 유 발하는 위험요인이었다(Choi \& Choi, 2013). 이처럼 직업적 음성사 용자의 음성은 직업의 종류와 음성사용환경, 근무환경의 특성뿐
만 아니라 이로 인한 개인적인 생활습관에도 영향을 받기 때문에 이에 따른 개별적인 음성오남용을 파악하고 조절하는 것이 음성건 강을 유지를 위해 중요하다. 하지만, 직업적 음성사용자인 언어재활 사의 음성사용습관이나 음성사용환경, 생활환경과 습관 등 언어 재활사의 음성오남용에 대한 연구는 교사와 같은 다른 직업적 음 성사용자에 비해 미비한 실정이다.

이에 따라 본 연구는 만성적인 음성문제에 대한 언어재활사의 주관적인 판단에 따라 음성문제가 있는 집단과 음성문제가 없는 집단으로 조작적 정의하여 음성문제 유무에 따른 음성오남용, VHI-10, 음성증상을 비교하고, 음성과 관련된 언어재활사의 경험 및 음성위생 준수에 대해 살펴봄으로써 언어재활사의 음성건강유 지를 위한 자가음성관리프로그램(self-voice care program) 개발의 기초자료로 사용하고자 한다.

\section{연구방법}

본 연구의 대상자는 연구자가 배포한 Google 온라인 설문에 응 답한 187 명의 한국 언어재활사이다. 연구대상자의 성별은 남 27 명, 여자 160 명이었으며, 연령은 20 대 111 명, 30대 57명, 40대 이상이 19 명이었다. 언어재활사 근무경력은 1년 미만 31명(16.6\%), 1년 이상 4 년 미만 61명(32.6\%), 4년 이상 7년 미만 61명(32.6\%), 7년 이상 34명 (18.2\%)이었으며 주당 치료 회기 수는 1-20회기 미만이 50명(26.7\%), 21-30회기가 60명(32.1\%), 31-40회기가 51명(27.3\%), 40회기 이상이 26명(13.9\%)이었다. 근무기관은 센터가 116명(62\%)으로 가장 많았 으며, 병원 31명(16.6\%), 복지관 18명(9.6\%), 학교/교육청 6명(3.2\%), 기타 16 명 $(8.55 \%)$ 이었다. 연구에 참여한 언어재활사의 학력은 전문대 졸 4명(2.1\%), 대학 졸 98 명(52.4\%), 학부비전공 석사 졸 20명(10.7\%), 학부전공 석사(수료/졸업) 58 명(31\%), 박사(재학, 수료, 졸업) 7명 (3.8\%)이었다(Table 1).

\section{설문지}

설문지는 임상가의 경험과 선행연구(Choi \& Choi, 2013; Song \& Pyo, 2010)를 참고하여 개발하였으며, 음성장애 영역뿐만 아니라 말, 언어문제를 보이는 소아를 평가하거나 치료하고 있는 1 급 언어 재활사 2 명에게 설문의 내용에 대한 피드백을 받아 최종적으로 완 성하였다. 설문내용은 성별, 연령, 근무경력, 주당 세션 수, 근무기 관, 학력등과 같은 기본적인 개별정보를 묻는 설문 1 과 주관적인 만 성적 음성문제 여부와 14 개의 주관적인 음성증상, 음성문제로 인 한 휴직경험이나 휴식의 필요성, 이비인후과 진료경험과 치료내용 에 관한 설문2, 음성오남용 확인 및 음성위생에 관한 대한 지식과 
Table 1. Participants' information

\begin{tabular}{lr}
\hline Characteristic & Value \\
\hline Gender & $27(14.4)$ \\
Male & $160(85.6)$ \\
Female & \\
Age (yr) & $111(59.4)$ \\
$20-29$ & $57(30.5)$ \\
$30-39$ & $19(10.2)$ \\
$\geq 40$ & \\
Career (yr) & $31(16.6)$ \\
$0-1$ & $61(32.6)$ \\
$1-4$ & $61(32.6)$ \\
$4-7$ & $34(18.2)$ \\
$\geq 7$ & \\
Session per week & $50(26.7)$ \\
$1-20$ & $60(32.1)$ \\
$21-30$ & $51(27.3)$ \\
$31-40$ & $26(13.9)$ \\
$\geq 40$ &
\end{tabular}

Values are presented as number (\%).

수행여부에 관한 설문3과 '소리 지르기, 큰 소리로 말하기, 오랜 시 간 동안 말하기, 시끄러운 환경에서 말하기, 과도한 말하기나 이야 기하기, 먼지 나는 곳에서 말하기, 속삭이기, 지나치게 크게 울거나 웃기, 노래 부르기, 자신의 음역보다 지나치게 낮거나 높은 상태로 노래하거나 말하기, 흡연, 알코올섭취, 카페인(커피, 녹차, 탄산음료 포함)섭취, 기침이나 목청 가다듬기'를 4 점 척도 $(1=$ 안함, $1=$ 가끔, 2 =보통, 3 =자주)로 평가하는 Choi와 Choi (2013)의 음성오남용 체크리스트와 한국판 음성장애지수-10 (Korean Voice Handicap Index-10, VHI-10; Yun, Kim, Son, \& Choi, 2008)로 구성하였으며, 설문1,2, 3은 Appendix 1에 제시하였다.

\section{자료의 수집과 분석}

자료 수집

연구자는 Google 온라인 설문지를 통해 2017년 10월 9일-11월 8 일까지 언어재활관련 온라인 커뮤니티에서 1 차 설문을 182 명, 12 월 2 일 언어치료인의 날 행사장에서 수기로 2 차 설문을 34 명 실시하여 총 216 명의 설문응답을 받았다. 이 가운데 정상적인 말이나 음성산 출에 영향을 미칠 수 있는 소화기계나 내분비계, 신경계의 질환 혹 은 정신과적 질환, 청각장애나 알레르기성 장애를 않고 있거나 상 기도 건조나 점막의 분비를 저하시킬 수 있는 경구용 피임약이나갑 상선 질환, 호르몬 계통의 약물 및 알레르기와 관련된 항히스타민제 와 같은 약물을 복용하는 경우는 제외하였다(Sataloff, Hawkshaw, \& Rosen, 1997). 최종적으로 187 명을 연구의 대상자로 하였다.

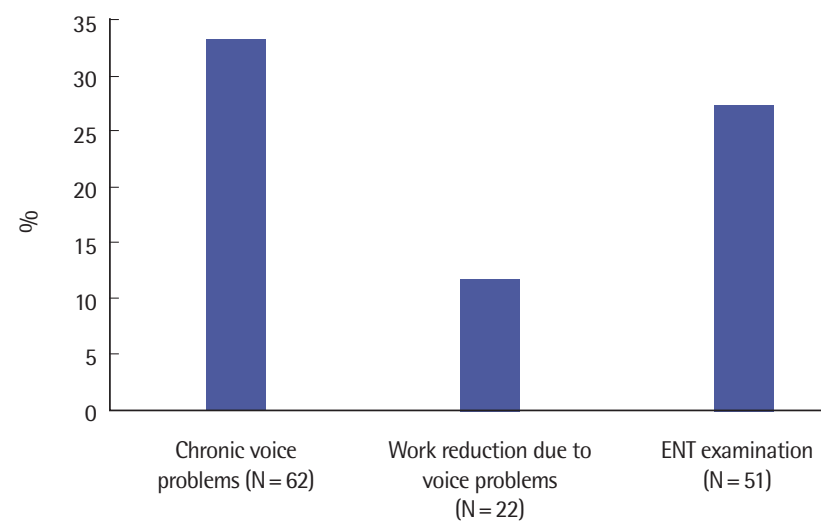

Figure 1. Experiences of relative to voice problem.

\section{자료 분석}

설문 $1,2,3$ 에서 예, 아니오로 대답이 가능한 문항과 음성오남용 체 크리스트는 명목변수로 처리하여 분석하였으며, 주관적 음성증상 선택문항에서 응답자가 선택한증상수의 합과음성오남용체크리스 트의 총 점수, VHI-10의 총 점수는 연속변수로 처리하여 분석하였다.

자료의 통계처리는 SPSS version 21을 이용하여 음성장애 유무, 음성오남용, 음성문제에 대한 인식과 음성위생과 같은 명목변수 항 목의 분석은 chi-square test를 사용하였다. 음성위생 수행 여부는 설문에서 음성위생 수행을 '아주 잘 수행한다 $(\mathrm{N}=0)$ ), '잘 수행한 다 $(\mathrm{N}=27)$ ', '보통으로 수행한다 $(\mathrm{N}=70)$ '라고 응답한 경우는 음성 위생을 잘 수행하는 집단으로 '거의 수행하지 않는다 $(\mathrm{N}=86)$ ', '전 혀 수행하지 않는다 $(\mathrm{N}=4)^{\prime}$ 라고 응답한 경우는 잘 수행하지 않는 집단으로 정의하였다. 음성장애 유무에 따른 VHI-10, 음성오남용 총점, 음성증상의 차이 비교는 Mann-Whitney rank sum test를 실 시하였으며, $95 \%$ 수준에서 유의성을 검증하였다.

\section{연구결과}

\section{음성문제와 관련된 경험}

Figure 1에 나타난 바와 같이 음성문제와 관련된 경험에 관한 설 문 중 음성사용의 불편함을 포함해 만성적인 음성문제 유무에 관 한 설문에 언어재활사의 $33.2 \%$ (62명)는 스스로 자신에게 만성적 인 음성문제가 있다고 응답하였다. 또한, 음성문제로 계획된 치료 세션을 감소 조절한 경험이 있는 언어재활사는 $11.7 \%$ (22명)이었으 며, $27.3 \%$ (51명)는 음성문제로 이비인후과에 내원한 경험이 있었 다. 이비인후과에 내원하여 권고 받은 치료는 음성휴식(침묵요법) $76.4 \%$ (39명), 약물치료 $62.7 \%$ (32명), 음성위생교육 및 음성위생지 속 $35.2 \%$ (18명), 음성치료 $5.8 \%$ (명), 후두미세술 1명(1.9\%)이었다. 


\section{음성오남용과 $\mathrm{VHI}-10$, 음성증상 간의 상관관계}

음성오남용과 VHI-10, 음성증상 간의 관련성을 알아보기 위해 Pearson 적률상관분석을 실시하였다. Table 2에 나타난 바와 같이 음성오남용 총점과 VHI-10 총점( $p=.000)$, 음성오남용 총점과 음 성증상 총점 $(p=.00), \mathrm{VHI}-10$ 총점과 음성증상 총점 $(p=.000)$ 간 유의한 정적 상관관계가 나타났다.

\section{음성문제에 대한 자가 인식과 음성위생 준수}

Table 3에 나타난 바와 같이 음성문제에 대한 자가 인식과 음성 위생 준수에 관한 설문에서 음성위생에 대한 지식은 $87.7 \%$ (164명) 가 음성위생에 대해 ‘안다’고 응답하였으며, 음성위생 수행을 묻는 설문에는 $51.9 \%$ (97명)가 ‘음성위생을 잘 수행한다’고 응답하였다.

Table 2. Correlations between vocal misuse and overuse total, VHI-10 total and voice symptom

\begin{tabular}{lccc}
\hline & $\begin{array}{c}\text { Vocal misuse and } \\
\text { overuse total }\end{array}$ & $\begin{array}{c}\text { VHI-10 } \\
\text { total }\end{array}$ & $\begin{array}{c}\text { Voice } \\
\text { symptom }\end{array}$ \\
\hline Vocal misuse and overuse total & 1 & $.353^{* *}$ & $.338^{* *}$ \\
VHI-10 total & - & 1 & $.434^{* *}$ \\
Voice symptom & $.338^{* *}$ & $.434^{* *}$ & 1 \\
\hline
\end{tabular}

VHI-10= Voice Handicap Index-10 (Yun, Kim, Son, \& Choi, 2008). ${ }^{* *} p<.01$.
자신의 음성오남용에 대해 자가 평가를 해본 경우는 50.3\% (94명) 이었으며, 매일 자신의 음성오남용에 대한 평가를 실시한다고 응답 한 경우는 $17.1 \%$ (32명)이었다.

음성문제가 있는 집단과 없는 집단 사이에 ‘음성위생 지식, 음성 위생 수행, 자가 음성사용 평가경험, 일일 자가 음성사용 평가'에 차 이가 있는지 비교하기 위해 chi-square test를 실시한 결과 음성문 제가 있는 집단과 음성문제가 없는 집단 사이에 ‘음성위생 수행’ 항 목에서 유의한 차이 $(p=.026)$ 가 나타났다.

\section{음성문제 유무에 따른 VHI-10, 음성오남용, 음성증상 차이}

음성문제가 있는 집단과 음성문제가 없는 집단의 VHI-10, 음성 오남용 정도, 음성위생 수행을 비교하기 위해 Mann-Whitney rank sum test를 실시한 결과, Table 4에 나타난 바와같이 VHI-10 ( $p=.000)$, 음성오남용 $(p=.001)$, 주관적 음성증상 $(p=.000)$ 의 점수가 음성문 제가 있는 집단이 음성문제가 없는 집단에 비해 통계적으로 유의 하게 더 높았다.

\section{음성문제 유무에 따른 오남용 특성}

Table 5에 음성문제 유무에 따라 음성오남용 항목에 대한 백분 율과 빈도수를 나타내었고, 두 집단 사이에 음성오남용 차이가 있

Table 3. Self-awareness of voice problems and vocal hygiene practice

\begin{tabular}{|c|c|c|c|c|c|}
\hline & & \multicolumn{2}{|c|}{ Chronic voice problem } & \multirow{2}{*}{$\chi^{2}$} & \multirow{2}{*}{$p$-value } \\
\hline & & Yes & No & & \\
\hline \multirow[t]{2}{*}{ Knowledge of voice hygiene } & Yes & $28.3(53)$ & $59.4(111)$ & 4.23 & .516 \\
\hline & No & $4.8(9)$ & $7.5(14)$ & & \\
\hline \multirow[t]{2}{*}{ Performance of vocal hygiene } & Yes & $13.4(25)$ & $38.5(72)$ & 4.955 & $.26^{*}$ \\
\hline & No & $19.8(37)$ & $28.3(53)$ & & \\
\hline \multirow[t]{2}{*}{ Self-evaluation experience for voice use } & Yes & $18.2(34)$ & $32.1(60)$ & .775 & .379 \\
\hline & No & $14.9(28)$ & $34.8(65)$ & & \\
\hline \multirow[t]{2}{*}{ Self-evaluation of daily voice use } & Yes & $8(15)$ & $9.1(17)$ & 3.279 & .70 \\
\hline & No & $25.1(47)$ & $57.8(108)$ & & \\
\hline
\end{tabular}

Values are presented as percentage (number).

${ }^{*} p<.05$.

Table 4. Difference comparison of vocal overuse and misuse, $\mathrm{VHI}-10$ and voice symptom according presence of voice problem

\begin{tabular}{|c|c|c|c|c|}
\hline & \multicolumn{2}{|c|}{ Chronic voice problem } & \multirow{2}{*}{$Z$} & \multirow{2}{*}{$p$-value } \\
\hline & Yes (N=62) & No $(N=125)$ & & \\
\hline VHI-10 total & $8.95 \pm 8.59(128.20)$ & $2.19 \pm 3.51(77.04)$ & -6.224 & $.000^{* * *}$ \\
\hline Vocal overuse and misuse & $22.29 \pm 5.7(113.40)$ & $18.98 \pm 6.04$ (84.38) & -3.485 & $.001^{* *}$ \\
\hline Voice symptom & $5.1 \pm 2.59(129.56)$ & $2.72 \pm 1.70(76.36)$ & -6.419 & $.000^{* * *}$ \\
\hline
\end{tabular}

Values are presented as mean $\pm \mathrm{SD}$ (mean rank).

VHI-10= Voice Handicap Index-10 (Yun, Kim, Son, \& Choi, 2008).

${ }^{* *} p<.01,{ }^{* * *} p<.001$. 
Table 5. Characteristics of vocal overuse and misuse in SLP with and without subjective voice problem

\begin{tabular}{|c|c|c|c|c|c|c|}
\hline & & \multicolumn{4}{|c|}{ Measure } & \multirow{2}{*}{$p$-value } \\
\hline & & 0 & 1 & 2 & 3 & \\
\hline \multirow[t]{2}{*}{ A loud speaking } & VP & $1(1.6)$ & $9(14.5)$ & $20(32.3)$ & $32(51.6)$ & \multirow[t]{2}{*}{$.028^{*}$} \\
\hline & NVP & $6(4.8)$ & $7(21.6)$ & $55(44)$ & $37(29.6)$ & \\
\hline \multirow[t]{2}{*}{ Speaking in a noisy environment } & VP & $5(8.1)$ & $21(33.9)$ & $17(27.4)$ & $19(30.6)$ & \multirow[t]{2}{*}{$.003^{* *}$} \\
\hline & NVP & $17(13.6)$ & $48(38.4)$ & $48(38.4)$ & $12(9.6)$ & \\
\hline \multirow[t]{2}{*}{ Speaking a lot } & VP & $3(4.8)$ & $10(16.1)$ & $17(27.4)$ & $32(51.6)$ & \multirow[t]{2}{*}{$.002^{* *}$} \\
\hline & NVP & $6(4.8)$ & $23(18.4)$ & $65(52)$ & $31(24.8)$ & \\
\hline \multirow[t]{2}{*}{ Speaking in dusty places } & VP & $10(16.1)$ & $17(27.4)$ & $26(41.9)$ & $9(14.5)$ & \multirow[t]{2}{*}{$.003^{* *}$} \\
\hline & NVP & 41 (32.8) & $46(36.8)$ & $32(25.6)$ & $6(4.8)$ & \\
\hline \multirow{2}{*}{$\begin{array}{l}\text { Speaking or singing in excessively high } \\
\text { or low pitch }\end{array}$} & VP & $5(8.1)$ & $18(29)$ & $23(37.1)$ & $16(25.8)$ & \multirow[t]{2}{*}{$.016^{*}$} \\
\hline & NVP & $34(27.2)$ & $35(28)$ & $36(28.8)$ & $20(16)$ & \\
\hline \multirow[t]{2}{*}{ Throat clearing } & VP & $3(4.8)$ & $18(29)$ & $22(35.5)$ & $19(30.6)$ & \multirow[t]{2}{*}{$.033^{*}$} \\
\hline & NVP & $19(15.2)$ & $45(36)$ & 41 (32.8) & $20(16)$ & \\
\hline
\end{tabular}

Values are presented as number (\%).

$\mathrm{SLP}=$ speech-language pathologist; $\mathrm{VP}=$ speech language pathologist with voice problem; $\mathrm{NVP}=$ speech language pathologist without voice problem. ${ }^{*} p<.05,{ }^{* *} p<.01$.

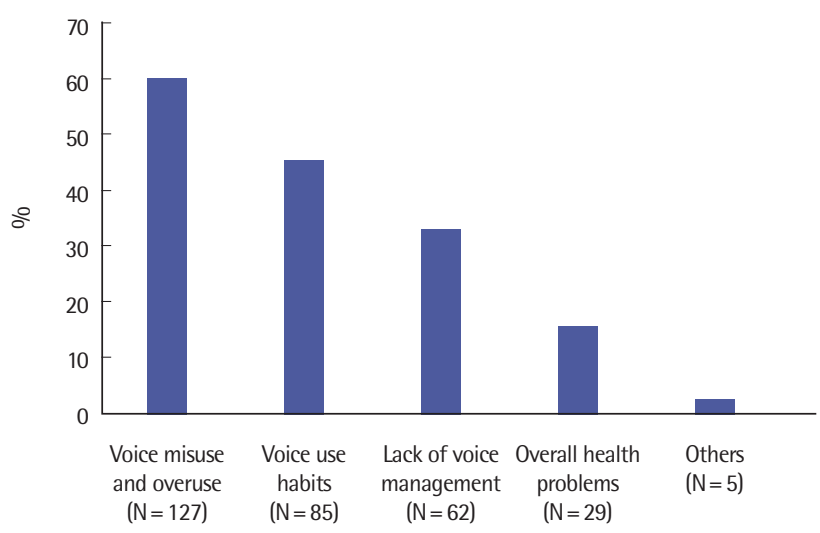

Figure 2. Causes of voice problems.

는지 알아보기 위해 chi-square test를 실시하였다. 그 결과, '소리 지 르기, 큰소리로 말하기, 오랜 시간 동안 말하기, 시끄러운 환경에서 말하기, 과도한 말하기나 이야기하기, 먼지 나는 곳에서 말하기, 속 삭이기, 지나치게 크게 울거나 웃기, 노래 부르기, 자신의 음역보다 지나치게 낮거나 높은 상태로 노래하거나 말하기, 흡연, 알코올섭 취, 카페인(커피, 탄산, 차)섭취, 기침이나 목청 가다듬기' 등 14 개의 오남용 항목 중 ‘큰소리로 말하기' ( $p=.028)$, '시끄러운 환경에서 말 하기' ( $p=.003)$, '오랜 시간 동안 말하기' ( $p=.002)$, '먼지 나는 곳에 서 말하기' ( $p=.003)$, '자신의 음역보다 지나치게 높거나 낮은 상태 로 말하거나 노래하기' ( $p=.016)$, '헛기침/목청 가다듬기' $(p=.033)$ 항목의 빈도가 음성문제가 있는 집단이 음성문제가 없는 집단보다 통계적으로 유의하게 높았다.

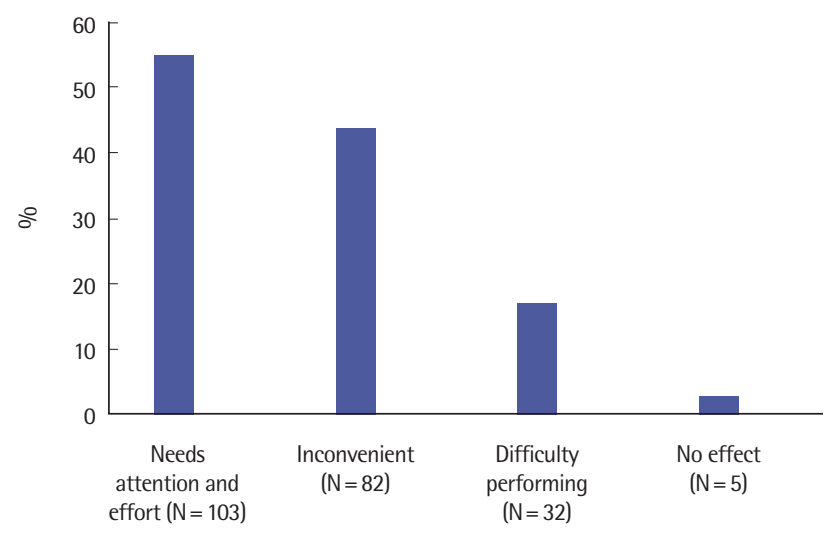

Figure 3. Cause of difficulty with vocal hygiene practice.

\section{음성문제의 원인}

Figure 2에 나타난 바와 같이 음성문제의 원인에 관한 설문에서 언어재활사의 $60.2 \%$ (127명)는 음성오남용, $45.4 \%$ (85명)는 음성사 용습관, $33.1 \%$ (62명)는 자발적인 음 성관리부족, $15.5 \%$ (29명)는 전 반적인 건강문제 때문이라고 응답하였다.

\section{음성위생 수행이 어려운 이유}

음성위생의 수행이 어려운 이유에 대한 설문에서는 Figure 3에 나타난 바와 같이 $55.1 \%$ (103명)가 '음성위생 준수에 많은 주의와 노력이 필요하다’라고 답했으며, $43.9 \%$ (82명)는 '음성위생 수행이 번거롭다', $17.1 \%$ (32명)는 '음성위생을 행동으로 옮기는 것 자체가 어렵다라고 응답하였다. 또한, $2.7 \%$ (5명)는 ‘음성위생이 효과가 없 


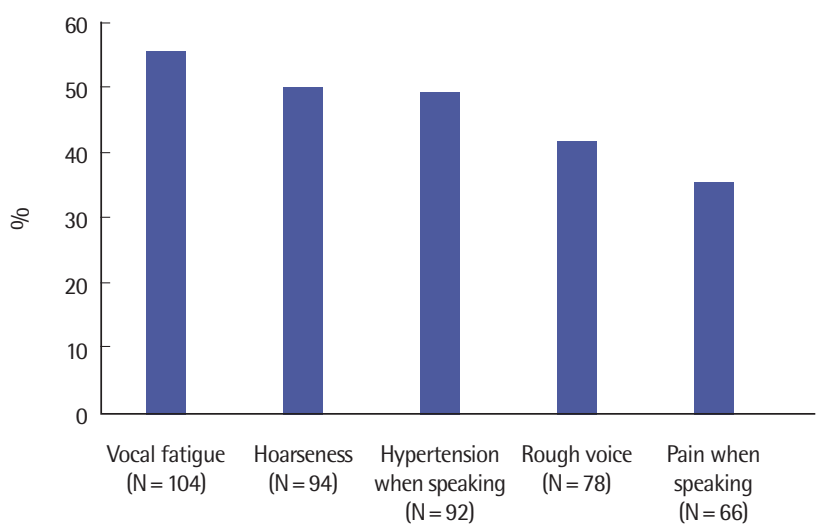

Figure 4. Subjective voice symptoms.

다'고 응답하였다.

\section{주관적인 음성증상}

Figure 4에 나타난 바와 같이 언어재활사로 일하면서 경험했거 나 현재 경험하고 있는 음성증상에 관한 설문에서 '바람 새는 소리, 음도상승, 음도저하, 쥐어짜는 소리, 약한 목소리, 쉰 목소리, 말할 때 목소리가 끊어짐, 말할 때 힘이 듦, 말할 때 목에 힘이 들어감, 말 할 때 목소리가 갈라짐, 말할 때 목에 통증, 음성피로감 경험, 노래 에서 고음 발성 곤란, 노래에서 저음발성 곤란, 기타' 가운데 가장 많은 비율을 차치한 음성증상은 음성피로감 $(55.6 \%, 104$ 명)이었으 며, 쉰 목소리(50.3\%, 94명), 말할 때 힘이 들어감(49.2\%, 92명), 거친 음성 $(41.7 \%, 78$ 명), 말할 때 통증 $(35.3 \%, 66$ 명), 말할 때 힘이 듦 $(28.3 \%$, 53 명), 노래에서 고음 발성 곤란(23.5\%, 44명) 순으로 높게 나타났다.

\section{논의 및 결론}

직업적 음성사용자인 언어재활사의 음성문제는 교사의 경우와 마찬가지로 개인의 삶의 질을 넘어 치료 서비스의 질과 효과로 이어 질 수 있는 중요한 문제인 만큼 이에 대한 관심과 연구가 필요하다. 본 연구는 언어재활사가 느끼는 주관적인 만성적 음성문제 유무에 따른 음성오남용 특성과 음성장애 정도 차이를 알아보고, 음성문 제와 관련된 음성위생 및 음성오남용 행동을 파악하여 언어재활사 의 음성건강유지를 자가음성관리프로그램 개발을 위한 기초자료 로 활용하고자하였다.

본 연구에서 자신에게 만성적인 음성문제가 있다고 보고한 언어 재활사는 $33.2 \%$ 였으며, $11.7 \%$ 는 음성문제로 인해 치료 수를 감소 조절한 적이 있었고, $25.7 \%$ 는 감소 조절하지 않았지만 휴식의 필요 성을 느꼈다고 응답하였다. 또한, $27.3 \%$ 는 음성문제로 이비인후과
에 내원한 경험이 있었다. 본 연구에서 나타난 언어재활사의 주관 적인 음성문제 유병률은 직업적 음성사용자군에 속하는 다른 직 업이나 언어재활사를 대상으로 한 선행연구에 비해 높았다. Song 과 Pyo (2010)는 언어재활사를 포함한 직업적 음성사용자의 음성 문제 유병률에 대한 선행연구가 거의 없고, 대상자의 주관이 개입 되는 설문지를 통한 연구는 샘플사이즈의 영향을 받을 수 있어 반 복적인 연구를 통한 데이터의 축적이 필요하다고 지적하였다. 이러 한 요인 때문에 본 연구에서 나타난 주관적 음성문제 유병률과 업 무제한, 진료경험에 대한 결과해석이나 고찰에 한계가 있겠지만, 언 어재활사라면 음성장애나음성위생, 음성치료 등에 대한 전문지식 을 갖추고 있는 만큼 성실하고 지속적으로 음성위생이 수행된다면 다른 직업적 음성사용자에 비해 그 효과가 더 크게 나타날 것으로 사료된다.

음성오남용과 VHI-10, 음성증상 간의 관련성을 알아보기 위해 실시한 상관분석에서는 음성오남용 증가에 따라 VHI-10, 음성증 상이 증가하는 정적 상관관계가 나타났다. 이러한 결과는 음성오 남용이 음성문제의 주된 요인인 동시에 음성오남용 조절이 주관적 으로 느끼는 음성문제와 음성증상을 개선시켜 줄 수 있는 방법임 을 시사한다.

음성문제에 대한 자가 인식과 음성위생, 음성오남용 조절 노력에 대한 설문에서 ‘음성위생 수행’은 유일하게 주관적인 음성문제 유 무와 유의한 상관이 나타났다. 이러한 결과는 언어재활사 역시 다 른 직업적 음성사용자와 마찬가지로 음성위생 수행을 통해 음성오 남용을 감소시킬 수 있음을 의미한다.

음성문제 유무에 따른 VHI-10 총점, 음성 오남용 총점, 음성증 상 총점을 비교한 결과, 음성문제가 있는 집단이 없는 집단에 비해 VHI-10, 음성오남용, 주관적 음성증상의 점수가 더 높았다. 먼저 VHI-10을 살펴보면 음성문제가 있는 집단의 경우 총점 8.95로 음 성문제가 없는 집단 2.19 에 비해 3 배 이상 높은 점수를 보였다. 주관 적인 음성증상은 음성문제가 없는 집단이 2.72 개인데 비해 음성문 제 집단은 5.1개로 더 많은 음성증상을 느끼는 것으로 나타났으며, 음성오남용 빈도를 나타내는 음성오남용 총점은 음성문제가 없는 집단 18.98 에 비해 음성문제 집단은 22.29 로 더 높게 나타났다. 음 성문제 유무에 따른 음성오남용 항목 비교 시 '소리 지르기', '큰소 리 말하기', '오랜 시간 동안 말하기', '시끄러운 환경에서 말하기', '과 도한 말하기나 이야기하기', ‘먼지 나는 곳에서 말하기', ‘속삭이기', '지나치게 크게 울거나 웃기', '노래 부르기', '자신의 음역보다 지나 치게 낮거나 높은 상태로 노래하거나 말하기', '흡연, '알코올 섭취', '카페인(커피, 탄산, 차)섭취', '기침이나 목청 가다듬기' 가운데 '큰 소리로 말하기', '시끄러운 환경에서 말하기', '오랜 시간 동안 말하 
기', '먼지 나는 곳에서 말하기', '자신의 음역보다 지나치게 높거나 낮은 상태로 말하거나 노래하기', ‘헛기침/목청 가다듬기'에서 음성 문제 집단이 유의하게 더 많은 빈도를 보였다. 동일한 음성오남용 항목으로 초등학교 여교사를 대상으로 한 Choi와 Choi (2013)에서 는 음성장애 유무에 따라 '큰소리로 말하기', '시끄러운 환경에서 말하기', 과도한 말하기나 이야기하기'에서 유의한 차이가 있었다. 하지만, 언어재활사와는 달리 수업 진행에 있어 자신의 음역대를 벗어나는 발성이나 노래를 할 필요가 없고 학생들을 수업에 참여시 키는 형태로 음성사용을 조절할 수 있으며, 교실의 환기에 어려움 이 없기 때문에 음역을 벗어나는 노래나 말하기, 오랜 시간 동안 말 하기나, 먼지 나는 곳에서 말하기 항목에 유의한 차이가 없었을 것 으로추측해볼 수 있다.

음성문제의 원인에 관한 설문에서 언어재활사는 그 원인을 음성 오남용(60.2\%), 음성사용습관 (45.4\%), 음성관리부족(33.1\%), 전반 적인 건강문제(15.5\%)라고 답했다. 이러한 결과는 언어재활사가 음 성위생과 음성오남용 조절과 같은 음성의 관리보다는 음성오남용 이나 발성습관과 같은 음성의 사용이 음성문제 발생에 더 중요하 다는 인식을 가지고 있음을 시사한다고 볼 수 있다. 음성위생 수행 이 어려운 이유에 대해서 연구에 참가한 언어재활사는 음성위생을 위해 ‘많은 주의와 노력이 필요하다' (55.1\%), '번거롭다' (43.9\%), '행 동에 옮기는 것이 어렵다’ (17.1\%)라고 응답하였다. 기존의 음성위 생은 음성에 영향을 줄수 있는 스트레스, 역류성 질환 등을 포함한 전반적인 건강관리와음성사용을 제한함으로써 발성 시 나타날 수 있는 진동외상을 예방하거나 손상된 성대미세구조의 회복을 촉진 하고, 성대의 점막파동 효율을 위해 쾌적한 환경의 유지와 성대가 건조하지 않고 습윤하도록 유지하는 데 초점을 맞추어왔다. 하지 만, 임상에서 가장 기본적인 방법으로 여겨지는 음성침묵이나 휴 식과 같이 음성사용의 제한이나 조절은 교사와 달리 비율제의 급 여체계를 가지고 있는 센터나 복지관에서 근무하는 언어재활사의 수입에 직접적으로 영향을 미칠 수 있어 현실적인 어려움이 따른 다. 본 연구에 참여한 언어재활사의 $62 \%$ 는 센터에서 근무하고 있었 는데 센터의 경우 치료 시 음성사용을 제한하거나 조절하는 것이 치료 서비스의 질을 급격하게 떨어뜨릴 수 있고, 환자나 보호자의 이의제기로 이어질 수 있다. 또한, 언어재활사의 근무환경은 대개 냉난방이 지속되거나 근무하는 치료실에 창문이 없는 경우도 있으 며, 치료 사이 쉬는 시간이 짧고 치료가 오후 시간에 연속되고 집중 되어 있기 때문에 언어재활사는 음성오남용과 음성위생에 대해 충 분한 지식을 가지고 있음에도 불구하고 자신의 음성오남용을 확인 하거나 음성을 위한 행동을 수행하기 위한 주의나 노력을 기울이 는 데 어려움이 따를 수밖에 없다. 직업적 음성사용자에게 음성의
사용은 수입이나 소득과 연관된 경제적 문제이기 때문에 음성의 불편함이나 문제가 있더라도 지속적으로 음성을 사용할 수밖에 없 는 강제성이 있다. 때문에, 언어재활사를 포함한 직업적 음성사용 자에게는 단순히 음성의 사용을 제한하거나 줄이는 음성오남용의 조절이 아니라 음성사용으로 인해 발생한 발성기관의 피로감이나 과긴장, 발성통과 같은 신체적인 차원의 문제해결을 촉진함으로써 효과적인 음성회복과 직업의 영위를 위한 음성사용이 지속적으로 순환될 수 있도록 음성오남용의 조절이나음성위생보다 더 넓은 개 념의 음성관리(voice care)가 필요하다고 할 수 있다. 또한, 선행연구 와 본 연구에서 언어재활사가 호소한 음성증상이 신체적, 생리적 차원에서 비롯되며, 기존에 사용되어온 음성위생법이 언어재활사 의 음성사용의 특성과 환경에 부족한 점도 있기 때문에 음성장애 환자에게 제시되는 보편적인 음성위생법과 함께, 발성 시 성대에 가 해지는 진동부담이나 충격 그리고 후두내근과 외근의 과긴장을 직 접적으로 이완시켜줄 수 있는 보다 적극적인 방법이 함께 제시되어 야할 것이며, 수행의 편리성과 효율성 또한 고려되어야 할 것이다.

Jin, Park, Lee, Lee와 Lee (1998)에서 직업적 음성사용자가 호소 하는 증상은 음성피로, 발성범위감소, 발성통, 애성 순이었고, Song 과 Pyo (2010)에서 언어재활사가 호소한 주요한 음성증상은 음성 피로(37.2\%)와 노래의 고음발성곤란(24.4\%), 말할 때 목소리 갈라 짐(24.4\%)이었다. 본 연구에서도 언어재활사로 일하면서 경험한 주 관적인 음성증상 중 가장 높은 순위를 차지한 증상은 음성피로 (55.6\%)였다. 교사, 성악가, 공연예술가와 같은 직업적 혹은 전문적 음성사용자들도 음성오남용으로 인하여 음성피로와 음성문제를 경험하는 것으로 보고하였고(Eustace, Stemple, \& Lee, 1996; Herrington-Hall, Lee, Stemple, Niemi, \& McHone, 1988), Kitch와 Oates (1994)의 연구에서는 배우나 성악가 집단에서 음성피로와 관련된 자각적 특징들을 보고하였는데, 목이 피로할 때 배우 집단 은 “힘”의 측면(예: 목소리 방사[voice projection])에 영향을 가장 많이 받는다고 하였으며, 성악가 집단에서는 목소리의 동적인 측면 (예: 음도 범위)에 가장 영향을 많이 받는다고 평가하였다. 본 연구 에서 언어재활사가 보고한 음성문제로는 피로감 외에 쉰 목소리 (50.3\%), 말할 때 힘이 들어감(49.2\%), 거친 음성(41.7\%), 말할 때 통 증(35.3\%), 말할 때 힘이 듦(28.3\%), 노래에서 고음발성 곤란(23.5\%) 순으로 높게 나타났는데, 이러한 결과는 선행연구와 일치하는 것으 로 가장 높은 순위를 차지한 음성피로와 더불어 고음발성 어려움 과 같은 발성범위감소, 발성 시 통증, 거칠고 바람 새는 듯한 음성을 의미하는 애성 또는 쉰 목소리 등은 용어의 차이일 뿐 동일한 증상 을 지칭하는 것이다. Hirano, Koike와 Joyner (1969)에 의하면 음성 피로는 음성오남용과 후두의 과긴장에 의한 것이며 Koufman과 
Blalock (1988) 역시 음성피로를 후두근육 긴장에 의한 것으로 갑 상피열근 약화와 관련 지으며 근긴장성 발성장애(muscle tension dysphonia, MTD)로 설명하였다. Jin (1997)에서 만성적인 음성피 로감를 호소하고 가시적인 병변이 없는 전화상담원의 $73 \%$ 는 후반 부 성문 틈이, $67 \%$ 는 진폭의 감소가 비디오스트로보스코피 검사 에서 관찰되었는데, 이는 Koufman과 Blalock (1991)이 분류한 MTD Type 1 와 유사한 형태이다. 본 연구는 온라인 설문을 통해 실 시되어 비디오스트로보스코피 검사를 실시할 수 없었지만, 참여 한 언어재활들이 호소한 증상이 음성피로감(55.6\%), 목 쉰 소리 (50.3\%), 말할 때 힘이 들어감(49.2\%), 거친 음성(41.7\%), 말할 때 통 증 $(35.3 \%)$ 으로 앞서 기술한 선행연구들과 유사하다는 점을 고려할 때, 언어재활사의 음성문제는 직업적 음성사용을 위한 지속적인 음성의 오남용으로 과긴장 되고 피로한 발성기관의 신체적인 문제 에서 비롯됨을 시사한다고 볼수 있다. 또한, 본 연구에서는 VHI-10 (Yun et al., 2008)의 결과를 신체영역, 기능영역, 정서영역별로 비교 하진 않았으나 음성문제가 있는 집단이 없는 집단에 비해 신체영역 에서 유의하게 더 높았는데, Song과 Pyo (2010)에서도 언어재활사 의 신체영역 점수의 중위수는 6.0 , 사분위수 범위는 7.3 으로 2.0 과 4.5 로 나타난 기능영역과 1.0 과 5.0으로 나타난 정서영역에 비해 높 았고, $\operatorname{Kim}$ (2017)에서도 신체영역의 평균은 10.9로 3.2로 나타난 기 능영역이나 2.05 로 나타난 정서영역에 비해 높았던 결과는 직업적 음성사용으로 인해 과긴장되고 피로한 발성기관으로 인해 음성문 제가 발생할 수 있음을 뒷받침하는 결과라고 볼 수 있다.

본 연구는 온라인 설문으로 실시하여 많은 수의 언어재활사를 대상으로 하였으나 음향학적 검사나 비디오스트로보스코피 같은 객관적인 평가를 실시하진 못하였다. 추후연구에서는 음향학적 검 사와 생리학적 검사, 음성과 관련된 삶의 질(V-RQOL), 음성피로도 (VFI) 등을 통해 언어재활사의 음성문제를 보다 다양한 관점에서 살펴볼 필요가 있겠으며, 음성에 영향을 미칠 수 있는 주당 치료 수 와 같은 직업적 음성사용량이나 음성위생의 수행도, 근무지와 근 무경력, 자격증 급수에 따라 언어재활사의 음성오남용과 음성위생 에 차이가 있는지 알아보는 것도 언어재활사의 음성문제를 파악하 는데 중요한 기초자료가 될 수 있을 것으로 사료된다.

\section{REFERENCES}

Cho, J. K. (2016). Acoustic Characteristics and vocal fatigue associated with professional voice use of female telemarketers (Master's thesis). Daegu Catholic Universtiy.

Choi, S. H., \& Choi, C. H. (2013). The characteristics of Voice Handicap In- dex and vocal misuse and overuse in female elementary teachers. Phonetics and Speech Sciences, 5, 53-61.

Eustace, C. S., Stemple, J. C., \& Lee, L. (1996). Objective measures of voice production in patients complaining of laryngeal fatigue. Journal of Voice, $10,146-154$.

Herrington-Hall, B. L., Lee, L., Stemple, J. C., Niemi, K. R., \& McHone, M. M. (1988). Description of laryngeal pathologies by age, sex, and occupation in a treatment-seeking sample. Journal of Speech and Hearing Disorders, 53, 57-64.

Hirano, M., Koike, Y., \& Joyner, J. (1969). Style of phonation: an electromyographic investigation of some laryngeal muscles. Archives of Otolaryngology, 89, 902-907.

Jacobson, B. H., Johnson, A., Grywalski, C., Silbergleit, A., Jacobson, G., Benninger, M. S., \& Newman, C. W. (1997). The voice handicap index (VHI): development and validation. American Journal of Speech-Language Pathology, 6, 66-70.

Jin, S. M (1997). Objective measures of voice production in telephone operators. The Journal of the Korean Society of Logopedics and Phoniatrics, 8, 3843.

Jin, S. M., Park, S. W., Lee, J. W., Lee, K. C., \& Lee, Y. B. (1998). Acoustic and stroboscopic characteristics in teachers, clergies and telephone operators. The Journal of the Korean Society of Logopedics and Phoniatrics, 9, 53-58.

Kim, M. J. (2017). Relationship between Vocal Fatigue Index and Voice Handicap Index for professional voice users (Master's thesis). Ewha Womans University, Seoul, Korrea.

Kitch, J. A., \& Oates, J. (1994). The perceptual features of vocal fatigue as selfreported by a group of actors and singers. Journal of Voice, 8, 207-214.

Koufman, J. A., \& Blalock, P. D. (1988). Vocal fatigue and dysphonia in the professional voice user: Bogart-Bacall syndrome. The Laryngoscope, 98, 493-498.

Koufman, J. A., \& Blalock, P. D. (1991). Functional voice disorders. Otolaryngologic Clinics of North America, 24, 1059-1073.

Koufman, J. A., \& Isaacson, G. (1991). The spectrum of vocal dysfunction. Otolaryngologic Clinics of North America, 24, 985-988.

Lee, S. (2017). A comparison of acoustics characteristics before and after speech therapy in speech language pathologist (Master's thesis). Myongji University, Seoul, Korea.

Pyo, H. Y. (2011). A qualitative study on voice use and evaluation of professional voice user patients. Korean Journal of Communication \& Disorders, $16,346-359$. 
Sataloff, R. T., Hawkshaw, M., \& Rosen, D. C. (1997). Medications: effects and side effects in professional voice users. In R. T. Sataloff (Ed.), Professional voice: the science and art of clinical care (2nd ed., pp. 457-470). San Diego, CA: Singular Publishing Group.

Seo, Y. K. (2016). Acoustic and aerodynamic characteristics of Clergy's voice (Master's thesis). Daegu Catholic University, Gyeongsan, Korea.
Song, Y. K., \& Pyo, H. Y. (2010). A preliminary study on voice symptoms and Korean Voice Handicap Index of speech language pathologists. Phonetics and Speech Sciences, 2, 123-133.

Yun, Y. S., Kim, H. H., Son, Y. I., \& Choi, H. S. (2008). Validation of the Korean Voice Handicap Index (K-VHI) and the clinical usefulness of Korean VHI-10. Korean Journal of Communication Disorders, 13, 216-241. 
Appendix 1. 언어재활사의 음성건강에 관한 설문

\section{언어재활사의 음성건강에 관한 설문}

\section{설문 1 기본정보}

1. 선생님의 성별은 어떻게 되십니까?
(1) 남
(2) 여

2. 선생님의 연령은 어떻게 되십니까?
(1) 20 대
(2) 30 대
(3) 40 대 이상

3. 선생님께서는 언어재활사로 일하신 지 얼마나 되셨습니까?
(1) 1 년 미만
(2) 1 년 이상-4년 미만
(3) 4년 이상 7년 미만
(4) 7 년 이상

4. 선생님께서는 현재 일주일에 평균 몇 회기를 치료하십니까?
(1) 20 회기 미만
(2) 21-30회기 미만
(3) 31-40회기 미만
(4) 40 회기 이상

5. 선생님께서 현재 근무 하시는 기관은?
(1) 센터
(2) 복지관
(3) 병원
(4) 학교/교육청
(5) 기타

6. 선생님의 최종학력은?
(1) 전문학사 졸업
(2) 학사 졸업
(3) 비전공학부 후 석사 졸업
(4) 학부전공 후 석사 수료/졸업
(5) 박사 재학/수료/졸업

7. 선생님께서는 소화기계나 내분비계, 신경계 질환 혹은 정신과적 질환, 청력장애, 알러지성 질환을 않고 계십니까?
(1) 예
(2) 아니오

8. 선생님께서는 경구용 피임약, 갑상선 질환, 호르몬 계통의 약물 및 알러지와 관련된 항 히스타민제와 같은 약물을 복용하십니까?
(1) 예
(2) 아니오

\section{설문 2 음성문제와 관련된 경험}

1. 선생님께서는 스스로 생각하시기에 음성사용의 불편함을 포함해 만성적인 음성문제를 가지고 계십니까?
(1) 예
(2) 아니오

2. 선생님 음성에 문제가 있다면 그 원인이 어디에 있다고 생각하십니까?
(1) 음성오남용
(2) 음성사용 습관
(3) 자발적인 음성관리 부족
(4) 건강문제
(5) 기타

3. 선생님께서는 음성문제로 언어재활을 쉬었던 경험(휴식)이 있습니까?
(1) 예
(2) 아니오
(3) 치료세션 감소
(4) 아니오, 그러나 쉴 필요를 느꼈다
(5) 기타

4. 다음 중에서 언어재활사로 일하시면서 경험했거나 현재 나타나고 있는 증상이 있다면 체크 해 주십시오(중복선택 가능)
$\square$ 바람 새는 소리
$\square$ 말할 때 목에 힘이 들어감
$\square$ 음도상승
$\square$ 말할 때 목소리가 갈라짐
$\square$ 음도저하
$\square$ 음성피로감 경험
$\square$ 쥐어짜는 소리
$\square$ 말할 때 목에 통증
$\square$ 쉰 목소리
$\square$ 노래에서 고음 발성 곤란
$\square$ 약한 목소리
$\square$ 말할 때 목소리가 끊어짐
$\square$ 말할 때 힘이 듦
$\square$ 노래에서 저음발성 곤란
$\square$ 기타

5. 선생님께서는 음성문제로 이비인후과 진료를 받으신 적이 있습니까?

$\begin{array}{ll}\text { (1) 예 (2)아니오 } & \end{array}$

6. 받으셨다면 어떤 치료를 받으셨습니까?(중복가능)

$\square$ 음성휴식(침묵요법;말하지마세요.)

$\square$ 약물치료

$\square$ 음성치료

$\square$ 음성위생교육 및 음성위생 지속

$\square$ 후두 미세술

\section{설문 3 음성위생과 오남용}

1. 선생님께서는 음성위생에 대해 알고 계십니까?
(1) 예
(2)아니오

2. 선생님께서는 음성위생을 수행하십니까?
(1) 아주 잘 수행한다
(2) 잘 수행한다
(3) 보통 수행한다
(4) 거의 수행하지 않는다
(5) 전혀 수행하지 않는다

3. 선생님께서는 자신의 음성사용이나 오남용을 평가해 보신 경험이 있으십니까?
(1) 예
(2) 아니오

4. 선생님께서는 매일 자신의 음성사용을 평가하거나 음성오남용 여부를 확인하십니까?
(1) 예
(2) 아니오 


\section{국문초록}

\section{한국 언어재활사들의 음성문제와 음성건강을 위한 자가관리현황 \\ 김지성 $\cdot$ 최성희 ${ }^{2}$ \\ ${ }^{1}$ 대구가톨릭대학교 대학원, 충북대학교병원 이비인후과, ${ }^{2}$ 대구가톨릭대학교 언어청각치료학과}

배경 및 목적: 언어재활사는 음성사용의 요구가 많은 직업으로서 음성문제는 임상 수행에 부정적인 영향을 미칠 수 있다. 본 연구는 우 리나라 언어재활사들의 음성문제와 음성관리 행태에 대해 조사하기 위하여 음성오남용과 음성위생 실천, 음성과 관련된 경험을 알아 보고, 주관적인 만성적 음성문제 유무에 따른 음성오남용, 음성장애지수, 음성증상을 비교하였다 방법: 언어재활사 187명에게 온라인 이나 오프라인으로 VHI-10과 음성증상, 음성오남용, 음성관련 경험에 대한 설문조사를 실시하고 그 내용을 분석하였다. 결과: 언어재 활사의 $33.2 \%$ 는 주관적인 만성적 음성문제가 있었고, 약 $50 \%$ 가 음성피로감과 쉰 목소리, 말할 때 힘이 들어가는 증상을 호소하였다. 음 성위생 수행이 어려운 이유로는 55.1\%가 음성위생 준수에 많은 주의와 노력이 필요하기 때문이라고 응답하였으며, 음성문제의 원인으 로는 $60.2 \%$ 가 음성오남용, $45.4 \%$ 는 음성사용 습관이라고 응답하였다. 자가음성문제가 있다고 보고한 언어재활사들이 없다고 보고한 언어재활사에 비해 통계적으로 유의하게 낮은 음성위생 수행과 높은 음성오남용 행동, 높은 음성장애지수를 보였다. 음성오남용, VHI10 , 음성증상은 정적 상관관계가 나타났다. 논의 및 결론: 언어재활사의 음성문제는 발성기관의 신체적인 피로에서 비롯되었다. 언어재 활사는 음성건강을 위해 음성위생과 자가 음성관리가 부족한 것으로 나타났다. 언어재활사의 음성건강을 위해서 언어재활사 개인 맞 춤형 예방적 음성위생법과 발성기관의 신체적 피로해소를 위한 보다 적극적인 자가음성관리실천이 필수적이다.

핵심어: 음성위생, 음성과 관련된 경험, 주관적 음성증상

본 연구는 2017년 언어재활사협회 역량강화사업의 지원을 받아 수행되었음.

\section{참고문헌}

김민주(2017). 직업적 음성 사용인의 음성피로도 검사(Vocal Fatigue Index)와 음성장애지수(Voice Handicap Index)의 상관도 연구. 이화여자대학 교 대학원 석사학위논문.

서영규(2016). 성직자 음성의 음향학적 공기역학적 특성. 대구가톨릭대학교 대학원 석사학위논문.

송윤경, 표화영(2010). 언어치료사의 음성증상 및 한국어판 음성장애지수에 대한 예비연구. 말소리와음성과학, 2, 123-133.

윤영선, 김향희, 손영익, 최홍식(2008). 한국어판 음성장애지수(Voice Handicap Index, VHI)의 타당도 및 VHI-10의 임상적 유용성. 언어청각장애연

구, 13, 216-241.

이솔(2017). 언어재활사의 언어치료 전·후음성 특성 변화 비교. 명지대학교 대학원 석사학위논문.

조재경(2016). 여성 텔레마케터의 직업적 음성사용에 따른 음성피로도와 음향학적 특성. 대구가톨릭대학교 대학원 석사학위논문.

진성민(1997). 교환수들의 음성발성에 대한 평가. 대한후두음성언어의학지, 8, 38-43.

진성민, 박상욱, 이정우, 이경철, 이용배(1998). 교사, 목사 및 교환수들의 음성발성에 대한음향분석학적 특징. 대한후두음성언어의학지, 9, 53-58.

최성희, 최철희(2013). 초등학교 여교사들의 음성장애지수와음성오남용특성. 말소리와음성과학, 5, 53-61.

표화영(2011). 직업적 음성사용인의 음성문제에 대한 질적 연구(1): 음성사용 실태와음성평가. 언어청각장애연구, 16, 346-359. 